\title{
3 On Ernst Papanek
}

The present chapter intends to provide a short introduction to the life and work of Ernst Papanek. ${ }^{105}$ He was born on 20 August 1900 to Johann and Rosa Papanek. With his two sisters Margarethe and Olga, Ernst and his family lived in Vienna's 6th district - Gumpendorfer Straße 122 - until 1911, before they moved to the 15th district. The family was Jewish, but not Orthodox, and religious rules and traditions were not really held in high regard. While Johann worked as a traveling salesman, Rosa was a tailor's assistant, and the family was making a living as part of the petty bourgeois community of Austria's capital. Regardless of his parents' disinterest in religious things, for a short time in his life, Ernst was very interested in all aspects of Jewishness and intended to become a rabbi in the future. However, like many other men and women of his generation, Papanek instead ended up being attracted by the ideas of socialism, as it presented a chance for true freedom and equality. ${ }^{106}$ It was therefore not surprising that the young man, who had supported the Austrian Emperor and the First world War at first, ${ }^{107}$ joined the Free Association of Socialist Middle School Students (Freie Vereinigung sozialistischer Mittelschüler) ${ }^{108}$ and became an active protester during the January Strike of $1918 .^{109}$ Papanek was arrested for the first

105 Unless indicated otherwise, this chapter follows the existent and more extensive outlines of Ernst Papanek's life and work in Maier, Auf Wiedersehen Kinder!, Papanek with Linn, Out of the Fire, and Papanek, "Als Jugendliche in den OSE-Heimen."

106 This decision was taken by many young Jewish women and men in the late 19th and early 20th centuries. See Alain Brossat and Sylvia Klingberg, Revolutionary Yiddishland: A History of Jewish Radicalism, transl. by David Fernbach (London/New York: Verso, 2016) and Frank Jacob and Sebastian Kunze, eds. Jewish Radicalisms. Historical Perspectives on a Phenomenon of Global Modernity (Berlin: De Gruyter, 2019).

107 Even critical Social Democrats in Germany, to name just one example, supported the war at first as they considered it to be a defensive one against Russia. For a detailed analysis of the development of anti-war criticism within the German Left, see Frank Jacob and Riccardo Altieri, eds. Krieg und Frieden im Spiegel des Sozialismus 1914-1918 (Berlin: Metropol, 2018).

108 This early socialist middle school organization did not exist for long, but the Association of Socialist Middle School Students (Vereinigung sozialistischer Mittelschüler) was established in 1923/24, followed, in 1925, by the Union of Socialist Middle School Students in Austria (Bund Sozialistischer Mittelschüler Österreichs). “Verband sozialistischer Mittelschüler (VSM),”Weblexikon der Wiener Sozialdemokratie. Accessed July 15, 2021. http://www.dasrotewien.at/ seite/verband-sozialistischer-mittelschueler-vsm.

109 The Jännerstreik was a transnational event, as many German cities reported massive strikes as well. Chaja Boebel and Lothar Wentzel, eds. Streiken gegen den Krieg: Die Bedeutung der Massenstreiks in der Metallindustrie vom Januar 1918 (Hamburg: VSA, 2008); Borislav Chernev, Twilight of Empire: The Brest-Litovsk Conference and the Remaking of East-Central Europe,

Ә Open Access. (C) 2021 Frank Jacob, published by De Gruyter. (c))BY-NC-ND This work is licensed under the Creative Commons Attribution-NonCommercial-NoDerivatives 4.0 International License.

https://doi.org/10.1515/9783110679410-003 
time due to his participation in an anti-war rally and for a second time in October 1918 when he handed out flyers on US President Wilson's 14 Points.

Regarding his own protest, Papanek was inspired by Fritz Adler (1879-1960), who had killed Austrian Prime Minister Karl von Stürgkh (1859-1916) to use a trial as a way to protest against the war. ${ }^{110}$ When Papanek and other students resisted being drafted for the army in 1918, they also hoped for a chance to stand trial and to publicly protest against the continuation of the First World War. However, the war ended before the young men could stage their criticism in a courtroom. Once the war had ended, Papanek began to work as a social worker and educator, although he had no official record of education for such a profession. However, together with around 400 senior high school students (Gymnasiasten) and university students, he organized a group called Playmates (Spielkameraden) that took care of war orphans and provided access to a soup kitchen for them and secured shelter in children's homes for them as well. ${ }^{111}$ On 8 July 1919, Papanek then finished his formal school education when he received his high school diploma (Matura). He then decided to study medicine and enrolled at the University of Vienna, where he would attend lectures in the fields of medicine, pediatrics, and psychiatry. While Papanek was enrolled for 12 semesters, in reality he was rather busy with his work for the Playmates, and, as family members reported later, the young man was more interested in saving the world than in finishing his university degree. ${ }^{112}$

1917-1918 (Toronto/London: University of Toronto Press, 2017), 107-152; Christian Koller, Streikkultur: Performanzen und Diskurse des Arbeitskampfes im schweizerisch-österreichischen Vergleich (1860-1950) (Vienna/Münster: LIT, 2009), 289-315. On Austria’s history in the revolutionary period at the end of the First World War see Hans Hautmann, "Österreich in der revolutionären Epoche 1917-1919," in Zeiten des Aufruhrs (1916-1921): Globale Proteste, Streiks und Revolutionen gegen den Ersten Weltkrieg und seine Auswirkungen, eds. Marcel Bois and Frank Jacob (Berlin: Metropol, 2020), 324-351.

110 John Zimmermann, “'Aber das Nichtstun gegen den Krieg ist auch eine Verantwortung für vergossenes Blut’: Friedrich Adler und sein Attentat auf den österreichischen Ministerpräsidenten Stürgkh 1916," in Krieg und Frieden im Spiegel des Sozialismus 1914-1918, eds. Frank Jacob and Riccardo Altieri (Berlin: Metropol, 2018), 285-307.

111 The situation during and after the war stimulated a professionalization with regard to the care for children and other people in need. Susanne Birgit Mittermeier, "Die Jugendfürsorgerin: Zur Professionalisierung der sozialen Kinder- und Jugendarbeit in der Wiener städtischen Fürsorge von den Anfängen bis zur Konstituierung des Berufsbildes Ende der 1920er Jahre," L'Homme: Zeitschrift für Feministische Geschichtswissenschaft 5, no. 2 (1994): 102-120. For a broader discussion, see Verena Pawlowsky and Harald Wendelin, Die Wunden des Staates: Kriegsopfer und Sozialstaat in Österreich 1914-1938 (Vienna/Cologne: Böhlau, 2015).

112 Maier, Auf Wiedersehen Kinder!, 24. 
Due to this care work for and with children, however, Papanek soon got involved with other projects. Dr. Eugenie Schwarzwald (1872-1940), ${ }^{113}$ a well-known Austrian pedagogue who established a vacation colony for Vienna's war-torn youth, recruited many people who had been active in the Middle School Movement as teachers, among them the 19-year-old Papanek, who would soon oversee one of the colonies, namely the one at the Emperor's villa (Kaiservilla) in Bad Ischl. In 1919/20, without a diploma or a finished degree, he then served as the leading director of Harthof am Semmering, one of the state education centers (Landeserziehungsheim) that Schwarzwald had established. A year later, Papanek was also active in supporting the Elderly Support movement (Greisenhilfe) that Schwarzwald had initiated in Vienna. Lilly Maier therefore emphasizes that "Papanek, with his humanitarian commitment to children and the elderly as well as his educational work, lived the social democratic ideals of Red Vienna." 114 In a later interview, Papanek remarked that "[w]e have all been pushed towards education. The Austrian Socialist Party saw politics as an educational problem." 115 The young Austrian pedagogue was consequently active in several organizations, like the Association of Socialist Students (Verband der Sozialistischen Studenten) and the Academic Legion (Akademische Legion), the fraternity of the Republican Protection Association (Republikanischer Schutzbund). ${ }^{116}$ In 1919, Papanek had also joined the Social Democratic Workers' Party (Sozialdemokratischen Arbeiterpartei, SDAP) and led holiday camps for, among others, the Red Falcons (Roten Falken), ${ }^{117}$ the Austrian socialist youth association. Due to these activities, Papanek would come into close contact with leading Social Democrats and Austromarxists, e.g. Fritz Adler, Otto Bauer (1881-1938), ${ }^{118}$ and Otto Felix Kanitz (1894-1940). ${ }^{119}$

113 On her life and work, see the recently published book Bettina Balàka, Über Eugenie Schwarzwald (Vienna: Mandelbaum, 2020).

114 Maier, Auf Wiedersehen Kinder!, 27.

115 Interview with Edward Linn, cited in ibid., 28.

116 On these organizations, see Wolfgang Speiser, Die sozialistischen Studenten Wiens 1927-1938 (Vienna: Europaverlag, 1986) and, with caution, Otto Naderer, Der bewaffnete Aufstand: Der Republikanische Schutzbund der österreichischen Sozialdemokratie und die militärische Vorbereitung auf den Bürgerkrieg (1923-1934) (Graz: Ares, 2004).

117 Helmut Uitz, Die österreichischen Kinderfreunde und roten Falken 1908-1938 (Vienna: Geyer, 1975).

118 Richard Saage, Otto Bauer: Ein Grenzgänger zwischen Reform und Revolution (Berlin: LIT Verlag, 2021).

119 Henriette Kotlan-Werner, Otto Felix Kanitz und der Schönbrunner Kreis: Die Arbeitsgemeinschaft sozialistischer Erzieher 1923-1934 (Vienna: Europaverlag, 1982). Kanitz had also 
As Papanek became more and more politically active, he decided to end his enrollment for a medical degree in 1925 and instead moved to the Philosophical Faculty of the university, as he had decided to pursue a degree to officially become a teacher, given that he was already working in this profession. Due to this decision, he came into contact with Otto Glöckel (1874-1935), who had founded the Pedagogical Institute at the University of Vienna in $1923^{120}$ and was an important figure in stimulating school reform in Austria. ${ }^{121}$ Papanek would be tremendously influenced by Glöckel's thoughts, and his later $\mathrm{PhD}$ thesis was dedicated to the Austrian school reform. ${ }^{122}$ Next to Glöckel, Papanek was also greatly influenced by Alfred Adler (1870-1937), ${ }^{123}$ the Austrian psychotherapist and the wellknown founder of a theoretical school of individual psychology. ${ }^{124}$ Alongside his official course plan, the young pedagogue also participated in some of Sigmund Freud's (1856-1939) private lectures, but the latter's antagonism toward Adler ${ }^{125}$ might have driven Papanek away. However, in contrast to his medicine course, he was a serious and hard-working student and finished his pedagogical education after only two years, on 1 July 1927. In his final thesis, "Individualistic and Collectivistic Education and School" (Die individualistische und kollektivistische Erziehung und Schule), ${ }^{126}$ Papanek could use information and experiences he had been able to gather as a student while working in nurseries and kindergartens in

written works on socialist education, e.g. Otto Felix Kanitz, Kämpfer der Zukunft. Eine systematische Darstellung der sozialistischen Erziehungsgrundsätze (Vienna: Jungbrunnen, 1929).

120 Claudia Beyerknecht, "Psychoanalytische Pädagogik und Montessori-Pädagogik in der Wiener Zwischenkriegszeit: Das wechselseitige Zusammenspiel von Psychoanalytischer Pädagogik und Montessori-Pädagogik im Wien der Zwischenkriegszeit und deren Repräsentation in der Zeitschrift für Psychoanalytische Pädagogik” (Thesis (Diplomarbeit), University of Vienna, 2012), 29.

121 Otto Glöckel, Die österreichische Schulreform: Einige Feststellungen im Kampfe gegen die Schulverderber (Vienna: Verlag der Wiener Volksbuchhandlung, 1923).

122 Ernst Papanek, The Austrian School Reform: Its Bases, Principles and Development (Westport, CT: Greenwood Press, 1978).

123 Bernhard Handlbauer, Die Entstehungsgeschichte der Individualpsychologie Alfred Adlers (Vienna: Geyer, 1984); Jürg Rüedi, Die Bedeutung Alfred Adlers für die Pädagogik: Eine historische Aufarbeitung der Individualpsychologie aus pädagogischer Perspektive (Bern/Stuttgart: Paul Haupt, 1988); Alexander Kluy, Alfred Adler: Die Vermessung der menschlichen Psyche (Munich: DVA, 2019).

124 Gabriele Rühl-Nawabi, "Pädagogische und therapeutische Grundlagen: Die Rezeption des individualpsychologischen Ansatzes Alfred Adlers durch Ernst Papanek," in Ernst Papanek: Pädagogische und therapeutische Arbeit - Kinder mit Verfolgungs-, Flucht- und Exilerfahrungen während der NS-Zeit, eds. Inge Hansen-Schaberg, Hanna Papanek and Gabriele Rühl-Nawabi (Vienna/Cologne/Weimar: Böhlau, 2015), 33-39.

125 Martin S. Fiebert, “In and Out of Freud's Shadow: A Chronology of Adler's Relationship with Freud,” Individual Psychology 53, no. 3 (1997): 241-269.

126 Maier, Auf Wiedersehen Kinder!, 31. 
addition to as an advisor for Vienna's welfare office. Glöckel's reforms would also offer him the first opportunities to apply progressive ideas for the actual education of students: "Within the Vienna school reform, Papanek was responsible for the restructuring of the advanced training schools, i.e. the schools for apprentices. As a young teacher, he taught in these schools himself and also ran an experimental daycare center for hard-to-educate, criminally convicted and neglected working-class children: the Sandleiten group."127

Next to his first successful steps in the professional world, Papanek also had the chance to start a family. In the Middle School Movement, he had met Helene (Lene) Goldstern (1901-1985), ${ }^{128}$ and although the two "were separated by worlds," 129 they would eventually become a couple and marry on 25 June 1925. Born into a rich Jewish family, she had studied medicine since 1919 and successfully finished her degree. Her father, Dr. Samuel Goldstern, was a well-known physician and director of the Fango Sanatorium for Rheumatic Diseases (Lazarettgasse 20) and demanded that Lene finish her medical degree before marrying Ernst because he intended her to become his successor as director of the clinic. Later, Lene was supposed to play an important role in the Children's Aid Society (Obsczestvo Sdravochraneniys Eryeyev, later Euvre de secours aux enfants, OSE) homes, where she acted as the institution's physician, but, as Hanna Papanek (born Hanna Kaiser, who later married Gustav Papanek), put it, she might have felt "overshadowed by Ernst's presence and could only make her stand in his absence.” ${ }^{130}$ Her son Gustav (Gus) Papanek would later state that Goldstern was not really fond of the idea that his daughter wanted to marry his father:

My grandfather Samuel was not at all enthusiastic about the idea that his daughter would marry this poor and radical boy who came from a very unimportant family. . . . In addition, Lene was considered the ugly sister in the family, and how could Ernst, who was popular with so many young women, want to marry her? Her father was convinced that Ernst only wanted to marry her because of her money. He told my mother that Ernst would never earn anything in his life, that he only ever cares about the party and political issues. ${ }^{131}$

Regardless of her father's resistance, Lene married Ernst, and their sons Gustav Fritz, named after Gustav Mahler (1860-1911) and Fritz Adler, and Georg Otto, named after Otto Bauer, were born on 12 July 1926 and 2 April 1931, respectively. After Gustav was born, the family moved to a Social Democratic housing scheme

127 Ibid., 32.

128 On her vita see ibid., 37-39.

129 Ibid., 37.

130 Papanek, “Als Jugendliche in den OSE-Heimen,” 215.

131 Cited in Maier, Auf Wiedersehen Kinder!, 41-42. 
at the Flötzersteig in Penzing, in the west of Vienna. Lene would commute for about an hour to her job at the clinic, while Papanek himself had been more and more drawn into political developments since the end of the 1920s.

In April 1932, he was elected to the City Council of Vienna, representing the 12th district, and he would also serve as a member of the Municipal Council Committee for Personnel Matters and Administrative Reform, overseeing the city's schools, kindergartens, and daycare facilities. Acting for the Social Democratic Workers' Party, he was also sent to Burgenland, a conservative stronghold, for an election campaign, where Papanek would try to gain some ground for the party. His lectures and speeches were often dangerous for him when the rage of the local population was directed against him, but Papanek remained optimistic. After the success of National Socialism in Germany in January 1933, the situation was becoming more and more worrying in Austria as well. As chairman of the Socialist Workers' Youth (Sozialistische Arbeiter-Jugend, SAJ) organization, Papanek and others tried to combine political resistance and educational measures, but when the Communist Party was banned in autumn 1933, the space for such activities got narrower. The last SDAP party convention was held on 14-15 October 1933, at which it was debated what preparations should be taken for a possible nationwide general strike and under which conditions the Social Democrats were supposed to take up arms against fascism.

It was the February Uprising in 1934 that would lead to open civil war in Austria $^{132}$ and force Papanek into exile, while "Red Vienna" was falling. In the following years, Austrofascism ${ }^{133}$ paved the way for unification with Adolf Hitler's (1889-1945) Germany in 1938. ${ }^{134}$ For Papanek, these events were crucial, as they forced him, like many other left politicians and Social Democrats, into exile. Regardless of his forced expatriation, he would nevertheless continue his work to support those who had had to stay in an Austria controlled by fascist forces.

The party leadership took refuge in Brünn (modern Brno, Czech Republic), where they established the Foreign Office of the Austrian Social Democrats (Auslandsbüro der österreichischen Sozialdemokraten, ALÖS) ${ }^{135}$ that was supposed to

132 Kurt Bauer, Der Februar-Aufstand 1934: Fakten und Mythen (Vienna/Cologne: Böhlau Verlag, 2019); Hans-Peter Weingand, Die KPÖ und der Februar 1934 (Graz: Clio Verlag, 2020).

133 Emmerich Tálos and Wolfgang Neugebauer, eds. Austrofaschismus: Politik, Ökonomie, Kultur, 1933-1938, fifth edition (Vienna: LIT, 2005).

134 Gerhard Botz, Wien vom "Anschluß” zum Krieg: Nationalsozialistische Machtübernahme und politisch-soziale Umgestaltung am Beispiel der Stadt Wien 1938/39, second edition (Vienna/ Munich: Jugend und Volk, 1978).

135 Dora Müller, Drehscheibe Brünn: Deutsche und österreichische Emigranten 1933-1939 (Brno: Deutscher Kulturverband, Region Brünn, 1997); Hans Christian Egger, "Die Politik der 
support party members who had remained in Austria. In addition, the ALÖS published the Workers' Journal (Arbeiter-Zeitung), whose first issue was published only seven days after the new headquarters in Brünn was opened. The journal was then illegally smuggled to Austria to support the anti-fascist resistance there. Papanek was charged with looking after the youth again and led a one-party committee that took on responsibility for all aspects related to the ALÖS youth organization. ${ }^{136}$ The SDAP was restructured and renamed as the Revolutionary Socialists (Revolutionäre Sozialisten, RS) ${ }^{137}$ and the SAJ became the Revolutionary Socialist Youth (Revolutionäre Sozialistische Jugend, RSJ). Papanek coordinated the activities of the RSJ and connected it with other illegal youth organizations. In addition, he authored a pamphlet about Josef Gerl, a worker who was responsible for an explosives attack on a signal system on the Danube Bank Railway (Donauuferbahn) on 20 July 1934 and was executed for it four days later. ${ }^{138}$ Alongside such activities, Papanek also served as the RSJ's representative at the International Union of Socialist Youth (IUSY), using the alias "Ernst Pek." He traveled a lot to coordinate the international activities of the RSJ before he was sent to Danzig in 1935 to support the anti-National Socialist election campaign with underground lectures. ${ }^{139}$ Papanek was able to work for just a few weeks before he was arrested by the National Socialists. It was only because he was helped by a member of the resistance who was serving as a security guard that the imprisoned Austrian was able to escape, and he was later smuggled out of Danzig to Denmark.

Papanek would remain in exile for the following years, although he was usually able to see his family during the summer and over Christmas, when Lene and the two boys visited him. During his exile years, on 6 November 1936, the Austrian pedagogue founded a journal, the International Pedagogical Information (Internationale Pädagogische Information, IPI), which was, however, only a short-lived endeavor to deal with educational and pedagogical questions from a transnational

\footnotetext{
Auslandsorganisationen der österreichischen Sozialdemokratie in den Jahren 1938 bis 1946: Denkstrukturen, Strategien, Auswirkungen” (PhD Thesis, University of Vienna, 2004).

136 Maier, Auf Wiedersehen Kinder!, 65-67; Papanek, "Als Jugendliche in den OSE-Heimen," 242-243.

137 Otto Bauer, Die illegale Partei (Paris: La Lutte Socialiste, 1939); Otto Leichter, Zwischen zwei Diktaturen: Österreichs Revolutionäre Sozialisten 1934-38 (Vienna: Europaverlag, 1978).

138 Sozialistischer Jugendverband für die deutschen Gebiete der Tschechoslowakischen Republik, ed. Die Idee steht höher als das Leben: Ein Buch über Josef Gerl und seine Freunde (Karlsbad: Graphia, 1935). Also see EPP, IISH, D-8.

139 Hansen-Schaberg, "Lebensgeschichtliche Hintergründe," 18; Maier, Auf Wiedersehen Kinder!, 69-71; Papanek, "Als Jugendliche in den OSE-Heimen," 238. On the election and the campaign work before, see Ernst Sodeikat, "Der Nationalsozialismus und die Danziger Opposition,” Vierteljahrshefte für Zeitgeschichte 12, no. 2 (1966): 139-174.
} 
perspective. The IPI was not openly socialist, but quite a lot of its articles presented socialist points of view on the issues that were presented in the journal. It was financial problems that forced Papanek to give up the project. The exiled politician and editor had in the meantime moved to Paris, where he lived on the Rue de la Glacière. ${ }^{140}$ When the Spanish Civil War began in 1936, between 800 and 2,000 Austrian volunteers ${ }^{141}$ would participate in it as part of the International Brigades, ${ }^{142}$ and it would not take long before Papanek also made his way to the war zone as a representative of the IUSY and the RSJ. In January 1937, he participated at the Congress of the Spanish Socialist Youth in Valencia, representing the IUSY. Six months later, in July 1937, he visited Madrid, and between 1936 and 1938, he also coordinated the aid and supply deliveries from the Workers' International to Spain. At the same time, he gained his first experience of refugee children who were brought to France or England after their parents had died due to the Civil War. $^{143}$

Papanek was again trying to save the world and took quite a lot of risks, while Lene was rather pessimistic and did not like the idea of her husband being in Spain during the Civil War. Gus Papanek commented on this difference between his parents as follows: "My mother was a pessimist. She didn’t want Ernst to go to Spain. She didn't want him to go to Danzig. Ernst was brave and absolutely convinced of his views and ideologies. And in doing so he was taking risks that Lene refused. But Ernst could be very stubborn."144 However, as a consequence of Hitler's early expansion and the Anschluss of Austria in 1938, the whole family would soon be united again, albeit still in exile. After a meeting with Otto Bauer, Fritz Adler, and Joseph Buttinger (1906-1992), ${ }^{145}$ the ALÖS had been dissolved on 1 April 1938. It was replaced by the Foreign Representation of Austrian Socialists (Auslandsvertretung der österreichischen Sozialisten, AVOES), which tried to continue to represent and support the resistance in Austria internationally as well as those who

140 Maier, Auf Wiedersehen Kinder!, 77.

141 Michel Lefebvre and Rémi Skoutelsky, Las brigadas internacionales (Barcelona: Lunwerg Editores, 2003), 16 counts 872 Austrians, the Documentary Archive of the Austrian Resistance (Dokumentationsarchiv des Österreichischen Widerstandes) states 1,400 (https://tinyurl.com/ 3bvtar4j) and Lilly Maier speaks of more than 2,000. Maier, Auf Wiedersehen Kinder!, 77. Since Austrians served in different brigades, it might be hard to determine a conclusive number.

142 On the International Brigades, see the recently published work Giles Tremlett, The International Brigades: Fascism, Freedom and the Spanish Civil War (London: Bloomsbury, 2020).

143 Richard W. B. Ellis, "Effects of War on Child Health," The British Medical Journal 1, no. 4544 (1948): 239-245.

144 Cited in Maier, Auf Wiedersehen Kinder!, 79.

145 Muriel Gardiner and Joseph Buttinger, Damit wir nicht vergessen: Unsere Jahre 1934 bis 1947 in Wien, Paris und New York (Vienna: Verlag der Weiner Volksbuchhandlung, 1978). 
had been forced into exile. In Vienna, the situation for the remaining members of the Papanek family also got worse. Lene's parents lost the clinic, while she was forced to continue to work there. It was in July 1938 when she took the boys and went to Paris by train. During the summer, the family spent time in La Baule (Bretagne), where Ernst was also taking care of some children of Austrian political exiles for the holiday season. In autumn 1938, the family returned to Paris, but money was tight, and the original plan had been to set sail for the United States as fast as possible.

Lene had already applied for the necessary visas for the US while she was still in Vienna and had also bought tickets for a round-trip so that the family could cash in for the return tickets once they reached the American shore. ${ }^{146}$ However, fate seemed to have a different task for Papanek. The OSE, ${ }^{147}$ which had been founded in Russia in 1912 but later moved its headquarters to Paris, wanted to establish children's homes in France for the children of political refugees, who had become quite numerous in recent years. They wanted Papanek to act as director of one of these homes but later offered him full control of all of them, which he would oversee as the leading director. ${ }^{148}$ Lene was against the offer, but Papanek, especially intrigued by the "free hand" he would be guaranteed as the leading director and by the idea of saving some money for the start of the family's new life in America, ${ }^{149}$ especially since work there seemed at first to be quite out of reach, ${ }^{150}$ accepted the job offer. He later explained: "To be perfectly frank, I took on the job originally for a limited time and for the most practical of all reasons: to put aside a little money. I was myself a political refugee. . . . It was not as a political man that the OSE wanted me, of course, but as a teacher."151 Once Papanek had visited the children's home in Montmorency, close to Paris, he decided to stay in France for six months to organize the OSE's new program for refugee children before moving to the US with his family, but, regardless of the arguments he had presented to Lene and his readers in his later writings, he confessed that he also had a moral obligation to not just leave these children behind: "[W]hile I may have been basing my argument to Lene solely on the

146 Papanek with Linn, Out of the Fire, 37.

147 Ibid., 34-35.

148 Ibid., 35.

149 "No, there was certainly nothing attractive enough about such an offer to tempt me to cancel our voyage to the United States. On the other hand, there was the question of how we were going to live once we got there.” Ibid., 35-36.

150 "I had no assurance of a job once we landed in America, for my English was, at best, primitive.” Ibid., 36.

151 Ibid., 33. 
opportunity it would give us to save up some money, I also had the queasy feeling that this was not a very good time for a man who had done so much talking about standing up to Hitler to be running off to America.”152

The OSE probably did not really foresee how progressive Papanek's pedagogical approach would be, and this would cause some issues with the rather conservative forces within the organization, but in November 1938 the Night of Broken Glass changed the character of the operation at large. As Maier emphasized, “[t]he children's home project in Montmorency took on a whole new meaning overnight. Instead of just helping children who were already in the country, the OSE and Ernst Papanek decided to bring children at risk to France."153 This meant that, actually, many more children would arrive and would have to be taken care of in the OSE's facilities. The transports were not solely run by the OSE, but also by the Central Child Reception Office (Bureau Central d'Accueil aux Enfants), the Rothschild Foundation (Fondation de Rothschild), and the Israelite Committee for Children from Germany and Central Europe (Comité Israélite pour les enfants venant d'Allemagne et d'Europe Centrale). In mid-February 1939, the French government granted 200 visas, and in February and March 1939, two transports arrived in Paris. ${ }^{154}$ In contrast to the children transported to England, ${ }^{155}$ the ones arriving in France were supposed to be housed collectively. Papanek had therefore established four children's homes in Montmorency, namely, the Villa Helvetia, the Villa La Chesnaie, Les Tourelles, and La Petite Colonie.

Financially, the establishment of the new homes was supported by Baroness Pierre de Gunzbourg, "the French wife of a Russian-born aristocrat," 156 who argued that she would only provide 40,000 Francs once, and not one centime more. Papanek, however, had identified the philanthropist in her from the start: "It was really very funny. The Baroness was an imposing woman, with hatchetlike features that she refused to make the slightest attempt to pretty over, and a warm, beautiful heart that she was always trying to hide."157 She emphasized that she was not helping these children because they were Jewish but because they needed support and it was a moral obligation. She took this

152 Ibid., 42.

153 Maier, Auf Wiedersehen Kinder!, 96.

154 Lilly Maier, "Rescued Twice: The French Kindertransport - Differences and Similarities to the British Kindertransport," Jewish Historical Studies 51, no. 1 (2020): 267-284.

155 Wolfgang Benz, ed. Die Kindertransporte 1938/39: Rettung und Integration (Frankfurt am Main: Fischer, 2003); Vera Fast, Children's Exodus: A History of the Kindertransport (London: I.B. Tauris, 2010); Rebekka Göpfert, Der Jüdische Kindertransport von Deutschland nach England 1938/1939: Geschichte und Erinnerung (Frankfurt am Main: Campus, 1999).

156 Papanek with Linn, Out of the Fire, 44.

157 Ibid., 45. 
obligation seriously, and "[t]hree weeks later, she gave us another forty thousand francs to buy a castle on the outskirts of Montmorency. Before the year was over, she had bought castles for us all over France at a cost of more than a million francs and was serving very actively as the chairman of our Board.”158

Before the first children's transport arrived from Germany and Austria in February 1939, the new homes for the children aged from 5 to 12 years old needed to be finished. It was the exile community that helped to prepare the children's homes: "They were working for the love of the children and they were happy for the chance to be working, and that meant they were working with enthusiasm. ... . [A] doctor became a mason, and a pretty darn good one. Lawyers became carpenters, professors became painters, former ministers of state became roofers, writers became laborers." furniture needed in different sizes for the respective age groups. A tailor shop was set up in the basement of one of the facilities and a shoemaker's workshop, too, as the children not only needed to be able to supply themselves but also to learn a trade at the same time. Of course, not everything went as initially planned, and there were problems in the early period when Papanek ran the children's homes in Montmorency, ${ }^{160}$ but when the children arrived, they at least had a place to feel safe again. How traumatized they were became obvious to Papanek and the other educators during their first meeting:

I explained that they were now going to have a little snack to eat and then go outside with their counselors and play until lunch was ready. A moment of silence. A somber-eyed, redheaded girl, about nine years old, raised her hand tentatively, and when I encouraged her to speak up she asked, in a sweet, tremulous little voice, "Are Jewish children also allowed to go into the park?" We were annihilated. It was all we could do not to rush out and throw our arms around her. What made it even more annihilating was that every other eye was turned up toward me waiting just as anxiously for the answer. When we did go outside, they just stood around waiting to be told what to do. They didn't ask any questions. They didn't even wander around aimlessly. They just followed whatever instructions or suggestions came their way. And so, at least, we knew what our first task was going to be. We were going to have to show them how to play. We were going to have to teach them how to be children. ${ }^{161}$

158 Ibid.

159 Ibid., 47.

160 Ernst Papanek, “Initial Problems of the Refugee Children's Homes in Montmorency, France," School and Society 57, no. 1467 (1943): 141-145, in EPP, IISH, C-11. Also see Ernst Papanek, "The Montmorency Period of the Child Care Program of the OSE," in In Fight for the Health of the Jewish People (50 Years OSE), ed. L. Wulman (New York: World Union OSE and The American Committee of OSE, 1968), 116-134, in EPP, IISH, C-44.

161 Papanek with Linn, Out of the Fire, 48. 
After having been told about their non-existent value to National Socialist society again and again, these children were suffering from many traumata, including an inferiority complex, as they had begun to doubt their own value as human beings. ${ }^{162}$ So the fact that they were treated like everybody else and they were allowed to act like children without any restriction based on their or their parents' identities came as a surprise to them.

Yet it was not only dealing with children who had been so traumatized for years that was problematic; initially, their different identities caused some tension as well. Papanek later described the three different groups of children whose members were "so distinctive that they never lost their identity."163 These three groups were:

The Orthodox, which was the only group we didn't try to break up.

The Cubans, who were not Cubans at all but rather the children of middle-class

Germans who had rented a luxury ship to take them to Cuba.

The Robinsoner, who were the children of political refugees who were already in France. ${ }^{164}$

The OSE home in Eaubonne would be used for Orthodox children. This was assumed to be the easiest way to keep them separate, as different rules, e.g. for food preparation, needed to be applied. However, the children were not properly categorized as Orthodox, so in some cases, children from a rather secular family would end up in the home for the Orthodox children. ${ }^{165}$ While daily life with these children was not always easy, ${ }^{166}$ Papanek tried to include them as much as possible as well. He was criticized for a lack of religiosity by the Orthodox faction within the OSE, especially since its members argued that Papanek did not pay enough attention to the Jewish rules and the Jewish identity of the children, but since he was supported by powerful donors who were rather more interested in humanitarian aid than religious lobbyism, his position was relatively secure.

The Cubans arrived after "they had been on the front page of the world's newspapers for three weeks and had been wandering around the ocean on the German luxury cruiser, St. Louis, for five." ${ }^{67}$ The attempt to bring their families to Cuba had failed, and the ship was then stuck at sea as nobody wanted to let

162 "All our children tried very hard to look energetic and useful and worthwhile when they first came to us. Having been so well instructed in their own inferiority, they automatically assumed that we too were judging them on their right to be alive." Ibid., 7.

163 Ibid., 51.

164 Ibid.

165 Ibid., 51-63. Also see Maier, Auf Wiedersehen Kinder!, 127-128.

166 Papanek, “Als Jugendliche in den OSE-Heimen,” 248.

167 Papanek with Linn, Out of the Fire, 63. 
them into their harbor at first. ${ }^{168}$ Eventually, 35 of these children arrived at Montmorency, and since they were mostly from bourgeois and educated families as well as being slightly older than the children already in the homes, they changed the dynamics a bit.

While the first two groups can easily be categorized according to religious and class-related aspects, the third one, the Robinsoner, was the politically determined group, in a way. ${ }^{169}$ They were "a small group of about thirty, all of them children of Social Democrat refugees, and almost half of them Gentiles. They came to us directly from a summer camp that had been run by the Red Falcons, the worldwide organization of Social Democrats for children between the ages of twelve and fourteen." 170 The Robinsoner arrived in September 1939 when the Second World War had begun, and this was the first time the OSE accepted children who had no connection to Jewry at all. This and their political preconditioning made them hard to integrate at first, but, regardless of the fact that all three groups kept their individual identities, the children eventually grew together to become one community. ${ }^{171}$

By 1939, there were 283 children in the OSE homes in Montmorency. ${ }^{172}$ For Papanek, it was important that the children stayed together and were educated in a way that would help them to overcome their multiple traumata while they learned something. The director of the OSE children's homes therefore demanded an anti-authoritarian kind of education, and he considered the children were best seen as a community, and living in this community would allow them to face their fears and nightmares together. He used methods Papanek had been testing since the end of the First World War, and " $[\mathrm{t}]$ he use of the first name, as the most outrageous symbol of our permissive policies, was one of the things that kept the Orthodox Community in a permanent state of discontent." ${ }^{173}$ However, Papanek was well aware that the choice of the right words and living conditions were now more important than ever for these children:

168 Georg Reinfelder, MS 'St. Louis’: Die Irrfahrt nach Kuba Frühjahr 1939 (Berlin: Hentrich \& Hentrich, 2002); United States Holocaust Memorial Museum, Washington, DC, "Voyage of the St. Louis,” last edited July 12, 2021. Accessed July 15, 2021. https://encyclopedia.ushmm.org/con tent/en/article/voyage-of-the-st-louis. Also see the respective chapters in Schöck-Quinteros, Loeber and Rau, eds. Keine Zuflucht.

169 Papanek with Linn, Out of the Fire, 76-83.

170 Ibid., 76. The summer camp was at Le Plessis-Robinson, the place their name actually referred to.

171 Maier, Auf Wiedersehen Kinder!, 136; Papanek, “Als Jugendliche in den OSE-Heimen,” 186.

172 Maier, Auf Wiedersehen Kinder!, 107.

173 Papanek with Linn, Out of the Fire, 87. 
[W]ords do carry their own symbolism, and as a practical politician I would be the last man in the world to underestimate the importance of symbols. With the Social Democrats, the exchange of first names was exactly that, a conscious symbol of the children's full status as comrades. And so it was with us. We were a community of children and adults, sharing a common danger and engaged in a common experiment. . . . I have always felt that the community can support the individual to a far greater extent than has ever been suggested. If we were to be a true community, if community living was to be given a fair chance, authority had to be based on something far more meaningful than Mister or Sir or, heaven help us, Herr Direktor. ${ }^{174}$

Papanek wanted the children to feel good and, in a way, at home and did not want them to replace their past, determined by oppression and discrimination, with a place that continued to give them a hard time and a bad feeling. For Papanek, as he described it later, "[i]t is the relationship between children and adults that primarily determines the atmosphere of an educational institution. The children had confidence in us only after we had earned their confidence." 175

In the first two weeks after their arrival, the children would usually gain 10 pounds in weight, but "[t]heir shrunken and shriveled self-esteem, their battered image of themselves, wasn't so easily handled. These were children who came to us in a kind of psychic shell shock. ${ }^{, 176}$ However, this shock hardly came as a surprise to Papanek and the other teachers at the OSE homes. The young girls and boys "had seen their parents murdered and beaten and humiliated and had themselves been systematically terrorized and publicly loathed. In a strange country, they were strangers and afraid. In the truest sense of the word, they were orphans. ${ }^{\text {"177 }}$ In this regard, the destructive force of National Socialism and the hypnotic spell of Hitler had "appl[ied] the psychology of terror on a scale so massive as to be unprecedented and . . . appl[ied] it, systematically, against children." 178 The situation was hardly understandable for the children, and Papanek, who was familiar with the work of Danish psychologist Irma Kessel, ${ }^{179}$ realized that they were torn between identities that had been imposed upon them, simultaneously considered as Jewish children, political enemies of the National Socialists, and refugees in a foreign country. They were in danger of losing themselves, and Papanek tried to avoid this. His educational methods and pedagogical considerations were consequently chosen to address these problems.

174 Ibid., 88.

175 Ibid.

176 Ibid., 95.

177 Ibid.

178 Ibid., 97.

179 Irma Kessel, Kinder klagen an! Zehn Kinderschicksale (Kopenhagen: Sexpol-Verlag, 1937). 
Papanek's pedagogical views had been highly influenced by Alfred Adler and his ideas of individual psychology (Individualpsychologie). ${ }^{180}$ It has been emphasized that the approaches Papanek chose to address the children's trauma in Montmorency are still important today, ${ }^{181}$ and the Austrian pedagogue clearly defined the aim he pursued:

Our first educational goal was to assure the children, explicitly and implicitly, that nothing that had happened to them had been their fault. The second was to convince them that the persecution they had suffered was not their inevitable fate as Jews. The third was to create an educational system that would return them to the world with a sense of pride, accomplishment and social consciousness. ${ }^{182}$

In short, Papanek intended to treat the children as human beings again who would thrive if not pressured and would be accepted as worthy members of the community at Montmorency: "The underlying concept here . . . is that the child who is given to discover for himself where his talents and interests lie will be far better equipped to adjust himself to the more complex problems that will arise later on in life when he had only his own resources to fall back upon." "183 Papanek's goal was simple, although not easy to achieve: "My goal was to see to it that these children who had been brutalized in so many ways not only survived but survived whole."184

The Austrian director of the OSE homes considered himself to be working on behalf of the parents of the children who lived in his facilities and did not intend to enter into competition with the former. In contrast, he encouraged them to write to their parents as often as possible, and there was a rule that every child was supposed to write a letter at least once every week. ${ }^{185}$ Furthermore, the children were supposed to face and maybe overcome their trauma as a group. For him, living in a collective was part of their therapy: "By keeping the children in touch with their parents, I was keeping them in touch with themselves."186 Papanek would, after

180 Gabriele Rühl-Nawabi, "Pädagogische und therapeutische Grundlagen: Die Rezeption des individualpsychologischen Ansatzes Alfred Adlers durch Ernst Papanek,” in Ernst Papanek: Pädagogische und therapeutische Arbeit - Kinder mit Verfolgungs-, Flucht- und Exilerfahrungen während der NS-Zeit, eds. Inge Hansen-Schaberg, Hanna Papanek and Gabriele Rühl-Nawabi (Vienna/Cologne/Weimar: Böhlau, 2015), 33-39.

181 Maier, Auf Wiedersehen Kinder!, 114. Also see Irene Etzersdorfer, "Osterreichische Sozialisten im französischen Exil: Aspekte zur Exilgeschichte österreichischer Revolutionärer Sozialisten in Frankreich 1938-1945” (PhD Thesis, University of Vienna, 1985), 133.

182 Papanek with Linn, Out of the Fire, 115-116.

183 Ibid., 116.

184 Ibid., 14.

185 Ibid.

186 Ibid. 
the first six months, extend his contract, as he argued that it was not the best idea simply to transfer the children to regular French schools after such a short time. In fact, the idealist and optimist Papanek had more in mind for the OSE children's homes than to act as simple stopover stations: "I was not, after all, an unknown quantity in the field of progressive education, and I was proposing the most massive experiment in progressive education ever attempted - saturation treatment, twenty-four hours a day."187

First of all, the children had to learn how to be alive and free again. The methods used by Papanek were consequently anti-authoritarian, which, as described above, confused the children at first. They could just call him "Ernst" and did not have to do homework, as the teachers "did not believe in stealing it [time] from them by assigning homework." 188 If the children were supposed to invest extra time, so was the teacher if additional tutoring was needed. To ease the children's transition and arrival in a foreign country, the lessons were taught in German for the first six months, which was especially crucial since many of the children had not had the opportunity to go to school in the last years. Yet after these first few months, the language of instruction was switched to French. Papanek wanted the children to feel integrated and act as such. He did not want them to accept a self-identification as a refugee because, as he explained later, "[i]f I had one overriding concern it was that we should not become a self-imposed ghetto. To give them a better understanding of French people and institutions, we planned excursions and trips and exchanged visits with the children of the village."189

There were also no grades. Instead, the children would receive a detailed report of their progress every three months that followed 24 existing categories, 12 positive and 12 negative. These were:
1) does his very best
2) is attentive and hard working
3) takes pains over his work
4) grasps things easily
5) is interested in the subject
6) expresses himself very well
7) concentrates on his work
8) shows perseverance
9) prepares his work well
10) shows comprehension, application and perseverance

187 Ibid., 117.

188 Ibid., 122.

189 Ibid., 126-127. 

11) shows initiative
12) shows imagination
13) could make greater efforts
14) is lazy and inattentive
15) does not take great pains
16) shows no understanding of the subject
17) is devoid of interest
18) has no ability to express himself
19) is superficial in his work
20) is without perseverance
21) does not prepare his work
22) shows a lack of knowledge caused by absence
23) is not very bright
24) shows a lack of imagination. ${ }^{190}$

These personal comments "were aimed at encouraging the child to keep working rather than at merely passing judgement on work that had already been done."191 As mentioned before, Papanek was not interested in sticking to a curriculum that solely helped the students to pass exams and to receive a diploma. He intended "to turn out skilled artisans" who could make an income once they left school, which was why "a great deal of attention was paid to manual instruction with all the children." ${ }^{\text {192 }}$ Papanek considered this to be important, especially considering the fact that the Second World War was already on their doorstep:

In an educational system which is truly geared to keeping instructions as close to life as possible, one also had to be mindful of the backgrounds of the children, the special circumstances under which they had come to us and the living conditions that probably awaited them. These were not children who had been sent to a boarding school by indulgent parents. They were children who would have to go out into the world to earn a living, possibly in a strange country, probably without any family tradition to guide them and certainly without any parental connections to smooth the way. ${ }^{193}$

Papanek considered these circumstances for the establishment of a student coadministration as another progressive aspect of life in the homes of Montmorency as well. ${ }^{194}$ There was a kind of formulated and publicly displayed constitution that

190 Ernst Papanek, "Home for Refugee Children of the O.S.E. Union in France (1940)," in EPP, NYPL, Box 8, 20-21.

191 Papanek with Linn, Out of the Fire, 131.

192 Ibid., 129.

193 Ibid.

194 Maier, Auf Wiedersehen Kinder!, 11, 108-110. 
secured the children some influence on the homes' administration, and in the case of disciplinary cases and the respective penalties or fines in particular, it was they who had to decide on the sentence in some kind of tribunal. Papanek hoped that the children would learn and get used to democratic processes by putting such a responsibility into their hands.

The children were granted many freedoms for a reason: "In tasting freedom, they tested freedom; and in the testing they learned that freedom without order can be a pain in the neck. " ${ }^{195}$ In addition to freedom, there should first and foremost be fun, which was supposed to make the children forget their pain and sorrow, at least for a moment. Birthday parties were big celebrations in the children's homes, although this was not the only reason to eat cake and have fun. The children celebrated all existent Jewish and French holidays alike, but if there was none at all, a reason for another party was easily found: "The world was a festival."196 The children also organized sports festivals, concerts, and theater plays. ${ }^{197}$ Once a visitor from the US described the homes as a kind of "Strauss operetta," a view Papanek did not share at all:

We were not a Strauss operetta. Neither were we one big theater party. We were a community of very special children with very special problems. They had come to us, strangers and afraid, and we had to make them happy again. Not merely by creating a well-ordered home. Not with parties or songs. When I speak of making them happy, I am not talking in terms of amusing them. Our task was to create an atmosphere in which they could develop and bloom again. ${ }^{198}$

Papanek was well aware that "his children" needed special treatment, especially since the wounds of their soul could not simply be addressed intellectually; one had to deal "with the[ir] emotions, and emotions travel on a separate wire. As long as the family remained intact, the emotional upheaval was held in check. It was death and separation that pulled the plug out, and we were a community of children without parents." 199 The children had experienced severe losses and were confronted with an imagined guilt, which Papanek also had to take into consideration when he decided about the form of daily life in the children's homes:

The haunting and sometimes unbearable vibrations from the past were one of the problems we had to address ourselves to. In every possible way that we could think of, we sought to instruct the children that:

195 Papanek with Linn, Out of the Fire, 139.

196 Ibid., 86.

197 Maier, Auf Wiedersehen Kinder!, 124.

198 Papanek with Linn, Out of the Fire, 86-87.

199 Ibid., 106. 
1) We were living in a time when very bad things were being done to many people, Jews among them.

2) This had come about as a result of a combination of historical and political events and was not directed against them as individuals.

3) They were not being individually punished for anything they had done for any congenital defect in themselves or their character. ${ }^{200}$

Regardless of the efforts invested by Papanek and the other staff members to create a secure and convenient space for the children, it was the war that would soon make reality catch up with these ambitions. The beginning of the Second World War had intensified the need for people to escape from the National Socialist regime and its troops that had begun to conquer Europe in the name of an ideology that considered both Papanek and the children in the OSE homes as its enemies.

The Papanek family had planned to leave France in October 1939, but the German invasion of Poland prevented this, although Papanek had at least been able to get a Swedish visa for his mother, sister, and brother-in-law. The war had also changed the dynamics of the work of the OSE, which could no longer wait for parents to assign their children to one of the homes; instead, one had to make sure that as many children as possible were evacuated from spheres of German influence. Due to the war, more homes, like the Villa Helvetica, ${ }^{201}$ needed to be opened to provide shelter for the higher numbers of children that were arriving. In addition, the children were now no longer able to keep in contact with their parents and were literally cut off from their former lives. ${ }^{202}$ Papanek would later describe his wartime experiences with the children in the OSE homes in Montmorency, and his words remind us what war actually meant for the hearts and souls of those who were the most vulnerable within human society. ${ }^{203}$

The Austrian pedagogue himself followed an order according to which all German and Austrian citizens living in France, who were considered "unwanted foreigners" (étrangers indésirables), had to register and get their paperwork checked while they were interned for the time being in one of several camps. ${ }^{204}$ That he answered this request and went to get registered was, in retrospect, "the worst mistake [he] ever made.”"205 Between 6 September and 4 November 1939, he

200 Ibid., 107.

201 Ibid., 44.

202 Maier, Auf Wiedersehen Kinder!, 136.

203 Ernst Papanek, "My Experiences With Children in War-Time," Trend (Quarterly Students Journal, New York School of Social Work, Columbia University) 4, no. 1 (1942): 6-8, in EPP, IISH, C-23.

204 Maier, Auf Wiedersehen Kinder!, 136.

205 Papanek with Linn, Out of the Fire, 133. 
was interned in several camps while Lene led the OSE children's homes - from 6 September onward in Maisons-Laffitte (Seine-et-Oise), between 5 October and 3 November in Domfront, and finally in Camp Damigny. ${ }^{206}$ His friends tried to get Papanek out of the internment camp quickly, and in contrast to many others, he only had to spend a relatively short time away from his family and the OSE homes. Since their visas had run out and their tickets to the US had been canceled, the Papaneks had to apply for new US visas. For the moment, they could only continue their work in the children's homes, where the arrival of the Robinsoner after the beginning of the war had created a few little problems as their presence interfered with the smooth continuation Papanek had hoped for, although the group was eventually integrated and became part of the children's community.

The war, however, also demanded that all people who were living and working in the OSE children's homes make adequate preparations. Air raids were soon quite common, and the children were drawn back into a world of violence that they had hoped to have left behind. ${ }^{207}$ Papanek spoke to them quite frankly about the war and the respective developments, as he wanted them to be aware of what would probably happen soon. However, he also understood that the children were being forced to confront their traumata again: "They not only saw themselves as the main object of the attack, they saw themselves as participants in the battle. For just so long as the adults were able to conceal their fear, the children of all ages behaved with courage and spirit." 208 It was consequently important to keep them busy so that they could focus on a task instead of their fear of another air raid or a German invasion that would again threaten their lives:

The environmental factors which have provoked the psychic trauma of European Jewish youth today have not always been of the same kind or the same power, though they have always had the same origin: Hitler's war of extermination on the Jews. There have been different developmental tendencies and phases. These alone could explain the often contradictory psychic reactions of young Jewish groups and individuals. But even psychic traumata of the same nature manifest themselves differently according to whether the

206 On the French internment policies, see Vincent Giraudier, Des indésirables: Les camps d'internement et de travail dans l'Ardèche et la Drôme durant la Seconde Guerre mondiale (Valence: Peuple libre, 1999); Guy Marchot, Les indésirables: Les camps d'internés civils français et étrangers, 1939-1946 (Aix-en-Provence: Association philatélique du pays d'Aix, 2020).

207 Ernst Papanek, “Children During Air Raids,” Progressive Education 19, no. 3 (1942): 157-159, in EPP, IISH, C-4. Also see Papanek with Linn, Out of the Fire, 22.

208 Ibid. 
trauma became effective in early childhood, after an emotionally calm and secure childhood, or after a childhood full of emotional privations, rejections and inhibitions. ${ }^{209}$

Papanek and his staff tried to keep the children's way of life as normal as possible to protect them from retraumatization, but they were not able to halt the course of history, and the Germans' success in Poland led to the German troops soon turning against France. In October 1939, the "children discovered what it was like to go about their schoolwork with the sound of gunfire off in the distance and the roar of planes overhead. They were able to find out what it was like to feel the floor shaking beneath their feet during the great air attack on Paris that killed fifteen hundred people." ${ }^{210}$ In the assemblies that were held in the morning, Papanek would explain the movements of the German army and its forces' respective strategic aims and the tactics that were applied. He did this for two reasons: "To begin with, they had a right to know what was happening. Beyond that, I wanted them to understand that nothing was happening accidentally. Because if nothing happened accidentally, they could not look upon themselves as helpless pawns of fate. With everything crumbling around them, I considered it more essential than ever to hold the great vision of a triumphant future before the children's eyes." ${ }^{211}$ Papanek also emphasized that the children would have to perform an important task: "As the inevitable survivors, it had fallen to us to preserve the culture of a civilized life - the highest impulses and the most noble aspirations of mankind - from being destroyed by the barbarism of war." ${ }^{212}$ For the moment, however, it seemed as if that barbarism was heading right for the children and was fully willing to destroy them first.

When Paris fell in June 1940, it was necessary to evacuate many of the 1,600 children that by then were living in the several OSE children's homes to safer places in southern France. In early June, there were still around 150 children in Montmorency, waiting for an uncertain future. It was decided to take them to Limoges, where a castle was supposed to be available to be their new home. Papanek and the children were able to get out of Paris ${ }^{213}$ and made it to the castle in Montintin, south of Limoges. ${ }^{214}$ The Austrian pedagogue could offer the owner 40,000 Francs in cash, which allowed the children to move into it: "Although the French aristocracy has been notably anti-Semitic since the Dreyfus Affair it has never been

209 Ernst Papanek, “[Report on] Social Service For European Jewish Children And Adolescents (1947),” EPP, NYPL, Box 8, 2.

210 Papanek with Linn, Out of the Fire, 29.

211 Ibid., 30.

212 Ibid.

213 Ibid., 167-179.

214 Maier, Auf Wiedersehen Kinder!, 149-155; Papanek with Linn, Out of the Fire, 181-201. 
known to permit its anti-Semitism, or anything else, to interfere with the greater pleasures that come from the pursuit of the franc. . . . I was practically buying the castle and leaving the title in his hands."215 The castle in Montintin was a suitable and exciting place for the children, as it was "a big medieval castle, completely broken down and yet not without a certain charm. Three stories, and a huge banquet room that brought to mind a picture of King Arthur's Round Table."216 Hanna Papanek would later refer to life at Montintin as a "youth paradise," though the war had forced the children to leave their new home in Montmorency again, at least they were safe for the moment. To keep it that way, Papanek decided to leave, together with his family, after he had been warned by the local police that his presence as a known socialist and anti-fascist could endanger the well-being of the children, especially since Philippe Petain's (1856-1951) Vichy Regime was likely to collaborate with the German occupation in the north of France. He had to make a hard choice, and only one day after their arrival, the Papanek family left Montintin for Montauban in southwest France. ${ }^{218} \mathrm{~Pa}$ panek left Asta Imbert as the new director, and although she was not as progressive as he was and would probably change some of his methods once she was in charge, Imbert had other qualities: she was "French, Catholic, and apolitical."219

When Papanek left, many children must have felt betrayed. ${ }^{220}$ Hanna Kaiser (later Papanek) noted in her diary: "One day Ernst left us with his whole family. We were left, abandoned, cynical and, for the first time, fearful. There might have been a reason for him to leave, some great danger - but even if we wanted to, we couldn't believe it." ${ }^{221}$ Papanek was later also criticized by some parents, as it was thought he had simply abandoned the children. The decision was not taken lightly, however, and it was supposed to serve the best interests of the rls and boys who would remain in Montintin. Even after leaving, Papanek invested a lot of energy to protect "his children." In Montauban, he met with Fritz Adler, from whom he was able to borrow some money that

215 Ibid., 184.

216 Ibid.

217 Papanek, “Als Jugendliche in den OSE-Heimen,” 186.

218 Maier, Auf Wiedersehen Kinder!, 157; Papanek, "Als Jugendliche in den OSE-Heimen,” 194-195.

219 Maier, Auf Wiedersehen Kinder!, 159; Papanek, “Als Jugendliche in den OSE-Heimen,” 255-257.

220 Maier, Auf Wiedersehen Kinder!, 159.

221 Cited in ibid., 160. 
would be used to secure food supplies for the children. In exchange, Papanek helped Adler to hide in the OSE children's homes for a while.

In the meantime, Lene's relatives, who were already in the US, were trying to help them with their visas, but it was the influence of Joseph Buttinger and Eleanor Roosevelt (1884-1962), who had founded the Emergency Rescue Committee, as well as William Green (1873-1952), the head of the American Federation of Labor, supported by Undersecretary of State Sumner Welles (1892-1961), who eventually secured some emergency visas from President Franklin D. Roosevelt (1882-1945), which were to help especially leading socialist figures who had to leave Europe immediately. ${ }^{222}$ The Papaneks, together with Oscar (1893-1963) and Marianne Pollak (1891-1963), were the first to use the Spanish Underground's route through France, Spain, and Portugal to get to the United States, although their visas for the US were considered to be fraudulent at first by the US consul in Marseille. However, once they were confirmed, the consul also helped to secure visas for Spain and Portugal. The trip from Montauban via Barcelona and Madrid to Lisbon would take 12 days, but it did not go as smoothly as planned or hoped for.

At the French-Spanish border, it took a while before the group was allowed to leave France, and in Barcelona, Georg showed symptoms of appendicitis. Lene was really worried about this situation: "If I say we have to send him to the hospital and you get caught and delivered over to Hitler, I'll feel I killed you. If I say we can go and his appendix bursts, I'll feel I killed him."223 So the couple checked the phonebook for Jewish-sounding physicians and called Dr. Abraham Levy, who, as it turned out, was also part of the Spanish Underground and with whom Papanek had already spoken about plans for how to get the OSE children out of France and en route to the US. The Papaneks reached Lisbon a few days later, and on 3 September 1940, they boarded the Nea Hellas, which would bring them to New York, where the family arrived on 12 September. The Underground's route had worked, and others would take it as well until Lion Feuchtwanger (1884-1958) frankly reported his escape from Europe in a newspaper interview and thereby ruined the route for anyone else who could have taken it after him. ${ }^{224}$ Papanek considered this interview to have been a political act rather than a stupid mistake: "The foolish act of a literary man unversed in the ways of the world, you may be thinking. Not at all. Lion Feuchtwanger knew exactly what he was doing because it seems to me inescapable that he was

222 Hansen-Schaberg, "Lebensgeschichtliche Hintergründe,” 14; Maier, Auf Wiedersehen Kinder!, 162-163; Papanek with Linn, Out of the Fire, 205.

223 Ibid., 209.

224 "Flight Described by Feuchtwanger: Refugees Here from Denmark and Germany," The New York Times, October 6, 1940. Also see material in EPP, IISH, E-9. 
doing it on orders. Feuchtwanger was a Communist and it is Communist policy to take credit for all revolutionary activity that proves to be effective and, where they cannot take credit, destroy it."225

While Papanek and his family had eventually reached safe territory, the children were still in danger and needed to be rescued as well. There were hundreds of them in the OSE homes, although the OSE itself had now become a rescue rather than a care facility. And regardless of the fact that Papanek's own life was not easy, he immediately began to network on behalf of the children, whom he wanted to bring to the US as fast as possible too. But at first, the family needed help themselves. They were moving quite a lot (151 West 94th Street, 155 West 84th Street, $410 \mathrm{~W}$ 110th Street), ${ }^{226}$ and their lack of money was problematic. The original idea that their income from working for the OSE would secure their start in the US turned out to be too optimistic, as Papanek had not yet been paid and would probably not receive any outstanding payment soon. From the Jewish Labor Committee, they received US\$ 90 a month. Lene and Ernst Papanek therefore had to work their way up again. Lene, who was not yet allowed to work as a medical doctor, found a job as a night nurse, while Ernst had to work as a dishwasher at a Horn \& Hardart restaurant. ${ }^{227}$ Regardless of these problems, he had at least thought that the organizations like the Jewish Labor Committee or the American branch of the OSE (AMROSE) would be able to help him with regard to the plan to rescue the children and bring them to America, but there seemed to be too many interests involved and "a maze of organizations"228 prevented fast action:

When life and death rides on every choice you must make, you remember only those whom you did not save. And that is the bitter irony of it: Those who did the most feel the most guilt. Those who did the least feel the least shame. It always happens when life and death are at the toss that there are those from whom no help is expected and you find help, and there are those who exist for no other purpose than to help, and they do nothing. It must be recorded that while thousands of children survived the Holocaust because the Underground was able to find shelter for them in monasteries, farmhouses and children's institutions throughout Europe . . . there were those in the United States from whom help had been confidently expected who did nothing. And in some cases, worse than nothing. 229

225 Papanek with Linn, Out of the Fire, 211.

226 Maier, Auf Wiedersehen Kinder!, 171.

227 Ibid., 172.

228 Papanek with Linn, Out of the Fire, 218.

229 Ibid., 31-32. 
In fact, Papanek was very disappointed, and in a later report to social worker Elsa Castendyck, who had served as the US delegate to the Advisory Committee on Social Questions of the League of Nations and who had previously visited the OSE homes in France, ${ }^{230}$ he argued:

As you know, I had resisted since 1940 the desire which was shared by you . . . to tell the whole history of what we sometimes thought was criminal misunderstanding and neglect when organizations and people tried to prevent by hook or crook to have the children from France come over to the U.S.A. I still believe that we should not attack some organizations, wrong as they were for their terrible and fateful mistakes, because they still have to request money from the public to do another kind of work which they do well and which is still necessary. ${ }^{231}$

There were rivalries and turf wars between the organizations Papanek had to deal with, which made it hard to actually gain what he needed: visas for the OSE children.

The United States Committee for the Care of European Children (USCOM), which coordinated the activities related to the issue, "had managed to obtain visas for English children, but they had little success, in the end, in cutting the red tape for Jewish children from the continent. . . . They would not, and could not, bring themselves to believe that the children were in mortal danger, because once they did it became incumbent upon them to move heaven on earth to rescue them."232 Time was of the essence, and Papanek lost it due to the named problems. It took until March 1941 for the first visas to be issued, and the slow processing was also a consequence of the fear of a wave of antisemitism if a large number of Jewish children were to be rescued. ${ }^{233}$ Eventually, however, the children were on their way, and Papanek would get involved in an argument that would have a great impact on their future. Children's homes, like the ones run by the OSE in France, were uncommon in the United States, where homes were rather used for juvenile criminals. Lotte Marcuse, a social worker for the German-Jewish Children's Aid, had to decide on the fate of the children, and in contrast to Papanek, she wanted them to leave their past behind and therefore intended to place them into foster families and break up the contact between them. Papanek would also not be allowed to get in contact with the children. The community he had built during their time in France

230 Castendyck shared Papanek's opinion about the necessity to protect refugee children better. Elsa Castendyck, "Refugee Children in Europe," Social Service Review 13, no. 4 (1939): 587-601. On her work in Europe, see Paul H. Stuart, "Refugee Children in Europe on the Eve of World War II," Journal of Community Practice 27, no. 2 (2019): 116-132.

231 Partial notes of a report by Ernst Papanek to Elsa Castendyck, n.d., EPP, IISH, E-5.

232 Papanek with Linn, Out of the Fire, 217.

233 Ibid., 218. 
was now considered improper, and the sense of belonging of the children was not valued highly enough to continue its existence.

That Papanek's ideas about children's homes were unpopular in the United States at that time became obvious during a lecture at the New York School of Social Work, when he was harshly criticized for his progressive ideas. ${ }^{234}$ Papanek realized that the term "institution" was connoted differently in the US to in Europe: "Of course. The home is the only sacred institution in America. I should have understood that.”235 In May 1941, the AMROSE explained that once the children were in the US, they were no longer their responsibility, and Papanek's contract that had just been renewed in March was terminated. Due to this decision, Marcuse was the one who would decide everything.

At least the children, who had been fed and hidden by the farmers of Limoges, were on their way. They also got the chance to pass by the internment and concentration camp at Gurs, where they could see some of their parents for a last time before they were brought to Lisbon. ${ }^{236}$ The first children's transport arrived in New York on 21 June 1941, and Papanek was happy to be able to meet the girls and boys, albeit only for a short time. That they were separated again after only a couple of days must have been heartbreaking, but Lotte Marcuse intended to break the old bonds, and the children were scattered across the country. During the second transport's arrival, this became even clearer: "What Mrs. Marcuse had in mind was a complete resettlement plan based on the incredible theory that the children must make a complete break with their past - as if she really believed it were possible to wipe the slate clean and begin all over again." ${ }^{237}$ When the ship with the children from the second transport arrived on 1 September 1941, Papanek was not allowed to see them at all. Gus Papanek later described the situation and the bitterness his father must have felt: "It was terrible for him. She [Marcuse] prohibited him from seeing the children. She had the power, and he had nothing." 238 There was a third transport that arrived in late September, and this time Papanek was able to secure at least a few hours with the children to explain the new situation to them and to break the news to them that they would be separated and would have to live with

234 Ibid., 221.

235 Ibid.

236 Michael Philipp, Gurs, ein Internierungslager in Südfrankreich, 1939-1943: Literarische Zeugnisse, Briefe, Berichte (Hamburg: Hamburger Institut für Sozialforschung, 1993); Hanna Schramm and Barbara Vormeier, Vivre à Gurs: Un camp de concentration français 1940-1941 (Paris: Maspero, 1979). Papanek argued that “Gurs had turned into the hellhole of France.” Papanek with Linn, Out of the Fire, 111.

237 Ibid., 241.

238 Maier, Auf Wiedersehen Kinder!, 192. 
foster families across the whole country. Of the 1,600 children in the French OSE homes, 253 had been brought to the United States, and the last of them arrived in July 1942. Those who remained in France suffered what Papanek called a second "Night of Broken Glass" when all the homes were raided on 26 August 1942. 69 children, including 11 from Montintin, were deported, and "the children who were taken from our Homes that night died in a rain of gas at Auschwitz."239 Although the French Resistance had attacked the deportation train with the OSE children and rescued and hid a large number of children, they obviously could not save all of them. Many more children were deported from France to be killed in Eastern Europe. ${ }^{240}$ When Papanek reached the news that Montintin had been raided, he must have felt devastated. A letter he received from France in September 1942 described the horrible events:

Last week we lived through a kind of St. Bartholomew's Massacre. At five o'clock in the morning we had guests with trucks at the door. They took a lot of people away with them. Then it was said that boys under eighteen would be released again, but in the meantime they were already sent further. Allegedly to Poland, but we don't really know anything definite. Among those taken mas Ernst Koppel, Benno Singer, Klans Martin. Guenther and Horst, who were with their parents on vacation, were also taken. And girls from the other houses. In the days that followed there was a hunt for those who had escaped, but the forests are large. There were tragicomic scenes as well. For instance, Friedman whom you know so well, slipped out of their hands twice. The second time he went to the toilet under guard, but he managed to escape from there too. Yesterday the little ones from our house was taken, allegedly to be taken to their parents in the concentration camps. They took even two year olds from their nurseries, and let them sleep at the railway station. What they intended to do with them we don't know. . . ${ }^{241}$

This made the trauma of those who survived the war and the crimes against humanity even worse. Papanek was a broken man, too, when he realized that he could not save all the children: "There are those who survived and found their lives, exactly as we had wished for them. There were those who survived into a vague, disquieting sense of guilt that they should have lived while so many died. There were those who did not survive and should have survived, and there is a bitterness about that which the years will never swallow."242 It became a burden for some to have survived while others had been killed and their memory

239 Papanek with Linn, Out of the Fire, 250. Papanek, “Als Jugendliche in den OSE-Heimen," 267-269 lists the known and recorded cases.

240 André Rosenberg, Les enfants dans la Shoah: La déportation des enfants juifs et tsiganes de France (Paris: Les Editions de Paris Max Chaleil, 2013).

241 Copy of a letter to Papanek, September 3, 1942, in: EPP, NYPL, Box 8.

242 Papanek with Linn, Out of the Fire, 31. 
threatened to fade away. Questions like "what if?” and "why?" haunted the minds of the survivors:

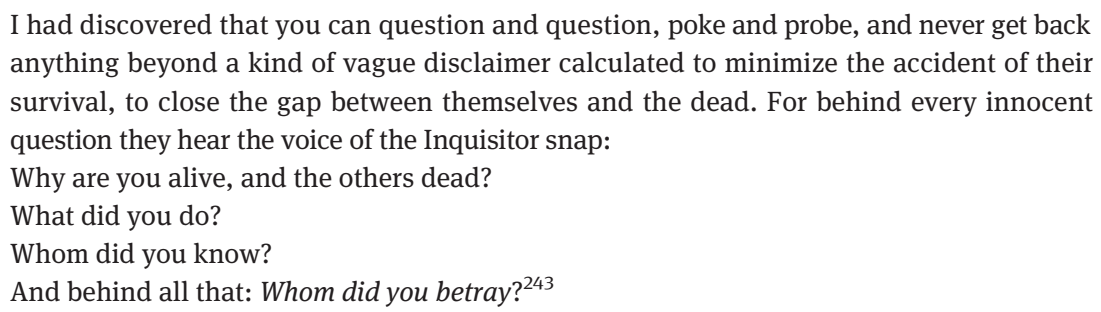

Some of the children, however, came to terms with their past when they realized for themselves that it had simply been down to luck that they had not been killed like so many others. ${ }^{244}$ In contrast to those who really quarreled with their fate, "[t] here were also those who set out to survive, refused to consider the possibility of not surviving and therefore accepted survival as no more than their due."245

For the Papaneks, a new life in the US began as well, and the Austrian pedagogue "reinvented himself."246 Lene began to work as a nurse in Vermont, and Ernst decided to enroll for a degree as a social worker at Columbia University. Gus moved out at the age of 15 to work on a farm in Ithaca and later studied agricultural economics at Cornell University. In 1943, Lene passed her National Board Exams and received her approbation as a medical doctor and thereby was allowed to work in her professional role again. Papanek finished his 170page long Master's thesis "On Refugee Children: A Preliminary Study," 247 and the family then moved to Elmhurst, where Lene opened a doctor's office. Papanek would soon start a new career as well, but he had been politically active in the US since his arrival, too. In 1941, he became a member of the American Socialist Party and the League of Industrial Democracy, and he worked for the Austrian Labor Committee as well as Austrian Labor Information. ${ }^{248}$ In addition, he founded American Youth for World Youth (AYWY), initially funded by the Unitarian Service Committee (USC), and organized relief supplies that were sent to Austria. In 1945, he was offered the position of director of the Children's

243 Ibid., 271. Papanek also witnessed "[t]he guilt of the survivor. I saw it unfold before my eyes in classic form soon after the war had ended.” Ibid., 273.

244 Ibid., 275.

245 Ibid., 275-276.

246 Maier, Auf Wiedersehen Kinder!, 12.

247 Ernst Papanek, “On Refugee Children: A Preliminary Study,” Final typescript, EPP, IISH, D-15.

248 Hansen-Schaberg, "Lebensgeschichtliche Hintergründe," 20. 
and Youth Welfare Organization of the USC, for which he and Lene would prepare training programs for staff who would be sent to Europe to work with children there. ${ }^{249}$ In 1946, Papanek also toured Europe to inspect children's homes for the United Nations, which had requested a report about the situation. ${ }^{250}$

It became more and more clear that Papanek, unlike other exiles, would not return to Europe. ${ }^{251}$ In 1947, Gus married Hanna Kaiser, and a year later, their son Thomas (Tom) was born. Papanek, who had eventually decided to stay, quit his job for the USC in 1948 and became director of the Brooklyn Training School and Home for Young Girls, where he intended to continue his pedagogical work. However, due to financial struggles, the school closed in 1949 and Papanek became director of the Wiltwyck School for Boys, 100 kilometers away from New York, in Esopus, Hudson Valley. He would stay there until 1958, and he had a tremendous impact on the young, mostly African American boys, including the boxer Floyd Patterson (1935-2006) and civil rights activist Claude Brown (1937-2002), ${ }^{252}$ among others. Papanek abolished corporal punishment and implemented many things he had already gathered experience of in France. In addition, he ignored racist habits in the United States and treated all of his students as equals. Next to individual and group therapy, he also used animal therapy and tried to provide many opportunities for sports events and outdoor activities. Again, he was able to create a sense of community. He made the trip to the institution once or twice a week, while he spent the rest of the week in his Manhatten office, meeting parents and attending court hearings. ${ }^{253}$

Papanek became an expert on juvenile delinquents and also finished his doctoral degree with his work on Austrian school reform in 1960. After quitting his job at the Wiltwyck School, Papanek taught at Queens College, where he served as Lecturer and then Professor of Pedagogy from 1959 until 1971. In addition, he taught at the New School for Social Research and spent some time in Japan as a Visiting Professor at the University of Hiroshima in 1966. In 1970, Papanek received the Golden Badge of the Association of Socialist Freedom Fighters and Victims of Fascism, and his work in France, as well as his political activities, received

249 Maier, Auf Wiedersehen Kinder!, 208.

250 Ibid., 210.

251 Marita Krauss, Heimkehr in ein fremdes Land: Geschichte der Remigration nach 1945 (Munich: C.H. Beck, 2001). On communists returning from the US to the German Democratic Republic, see Mario Keßler, Westemigranten: Deutsche Kommunisten zwischen USA-Exil und DDR (Cologne: Böhlau, 2019).

252 Claude Brown reflected upon his time at the school and Papanek himself in his autobiographical novel Manchild in the Promised Land (New York: Macmillan, 1965).

253 Maier, Auf Wiedersehen Kinder!, 220-223. 
recognition. At the same time, Lene made quite a career for herself as well, as she enrolled in a program for psychiatrists and later opened a very successful office in Manhattan. In addition, she acted as a director of the Alfred Adler Institute in New York. Finally, the Papaneks had reached the social and cultural elite of their new home country. Many of the children from the OSE homes were similarly successful. ${ }^{254}$ Hanna Papanek emphasized how indispensable the children were for her father-in-law. She also highlighted with regard to Papanek's and the children's historical significance that "[i]t is indispensable to remember these children us - because the love for people, the respect for each person, the tolerance, the collective feeling, the self-confidence that we experienced and learned in 'his' homes are his legacy."255

254 Ibid., 255-267 provides some insight on the fate of some of the children. Also see Lilly Maier, Arthur und Lilly: Das Mädchen und der Holocaust-Uberlebende - Zwei Leben, eine Geschichte (Munich: Heyne, 2018).

255 Papanek, “Als Jugendliche in den OSE-Heimen,” 266. 
